\section{Carbon Isotope Discrimination Correlates with Bean Yield of Diverse Coffee Seedling Populations}

\author{
F.C. Meinzer, J.L. Ingamells, and C. Crisosto ${ }^{1}$ \\ Crop Science Department, Hawaiian Sugar Planters' Association, P.O. \\ Box 1057, Aiea, HI 96701
}

Additional index words. Coffea arabica

\begin{abstract}
Foliar C isotope discrimination $(\Delta)$ and yield of green coffee (Coffea arabica L.) beans were evaluated for seedling populations from 14 diverse coffee cultivars growing in Hawaii. A was negatively correlated with yield of green coffee beans. The $2 \%$ variation in A observed in leaves sampled about 2 months after completion of the first harvest corresponded to a 3-fold variation in yield. Substantial variation in A exists among coffee cultivars, and foliar A analyses show promise as a means of selecting superior genotypes of long-lived woody crops.
\end{abstract}

Discrimination $(\Delta)$ against the naturally occurring stable isotope ${ }^{13} \mathrm{C}$ occurs during photosynthetic $\mathrm{CO}_{2}$ fixation in $\mathrm{C}_{3}$ plants (Farquhar et al., 1989). This discrimination has a biochemical component and a diffusional component that cause the relative ${ }^{13} \mathrm{C}:{ }^{12} \mathrm{C}$ ratio $\left(\delta^{13} \mathrm{C}\right)$ in plant tissue to be lower than that in the bulk atmospheric pool of $\mathrm{CO}_{2}$. The magnitude of $\mathrm{A}$ and the resulting $\mathrm{C}$ isotope composition of leaf tissue are determined largely by the ratio of intercellular 10 atmospheric partial pressure of $\mathrm{CO}_{2}$ $\left(\mathrm{p}_{\mathrm{i}}: \mathrm{p}_{\mathrm{a}}\right)$ that prevails when the tissue $\mathrm{C}$ is assimilated (Farquhar et al., 1982). The $\mathrm{p}_{\mathrm{i}}$ : $\mathrm{p}_{\mathrm{a}}$ ratio is also directly related to the ratio of the instantaneous rates of $\mathrm{CO}_{2}$ assimilation and stomatal conductance, a measure of intrinsic water-use efficiency (WUE).

The latter relationship has been exploited to establish correlations between $\Delta$ of leaf tissue and WUE for several crop (Farquhar and Richards, 1984; Martin and Thorstenson, 1988; Meinzer et al., 1990; Wright et al., 1988) and native species (Farquhar et al., 1989; Johnson et al., 1990). These studies have been extended to evaluate the potential use of variation in $\Delta$ among genotypes grown under identical conditions as a means of selecting for improved WUE. Recently, $\Delta$ has also been reported to be correlated with yield in both $\mathrm{C}_{3}$ (Condon et al., 1987; Hubick et al., 1986; Johnson et al., 1990) and $\mathrm{C}_{4}$ (Hubick et al., 1990) crop species. Stable $\mathrm{C}$ isotope analysis shows promise as a screening tool for identifying germplasm with superior performance with respect IO yield and WUE because tissue $\Delta$ is an integrated measure of internal plant physiological and external environmental properties

Received for publication 19 Nov. 1990. Published as paper no. 745 in the journal series of the Experiment Station, Hawaiian Sugar Planters' Assn. The cost of publishing this paper was defrayed in part by the payment of page charges. Under-postal regulations, this paper therefore must be hereby marked advertisement solely to indicate this fact. ${ }^{1}$ Current address: Dept. of Pomology, Univ. of California, Davis, CA 95616. influencing performance during the entire life of the plant.

The objectives of the present study were to assess the genetic variation in $\mathrm{C}$ isotope composition of diverse coffee cultivars and determine whether leaf $\Delta$ values were correlated with final yield of green coffee beans. In a previous study with coffee, leaf $\mathrm{C}$ isotope composition was highly correlated with inherent WUE determined by gas exchange techniques (Meinzer et al., 1990). The range of A values obtained corresponded to a $30 \%$ genotypic variation in inherent WUE.

Seedlings of 14 Coffea arabica cultivars (i.e., seedling populations, see Table 1) were planted during Nov. 1987 in a field near Waipahu, Hawaii (lat. $21^{\circ} 21$ ”N, long. $158^{\circ} 02^{\prime} \mathrm{W}$, alt. $100 \mathrm{~m}$ ) at a spacing of $1 \mathrm{~m}$ between plants and $3.7 \mathrm{~m}$ between rows. The plants were grown in full sunlight and were irrigated weekly through drip emitters placed along the center of each row.

Leaf samples for $\Delta$ analysis were taken from five sample plants of each seedling population in each of three replicate blocks during June 1988, before the plants had flowered, and again during Mar. 1990, ₹2 months after completion of the first harvest. Previous phenological observations indiNov. 1987.

${ }^{\mathrm{z}}$ Mean \pm SE of six replicate plots containing three plants each. cated that the leaves collected after harvest had been produced about the middle of the harvest period. The samples were pooled according to seedling population, oven-dried at $70 \mathrm{C}$, and finely ground. The relative abundance of ${ }^{13} \mathrm{C}$ and ${ }^{12} \mathrm{C}$ in the $\mathrm{CO}_{2}$ produced from combustion of the samples was analyzed by mass spectrometry as described by Meinzer et al. (1990). Isotopic discrimination was calculated according to Farquhar and Richards (1984). Replicate analyses of tissue were within $0.1 \%$ of each other.

Yield was determined by manually harvesting ripe fruits from three sample plants in each of six replicate plots for each seedling population at monthly intervals from Aug. 1989 through Jan. 1990. There were two plots in each of the three blocks from which leaf samples for $\mathrm{C}$ isotope analysis were obtained. Yields obtained do not represent maximum yield potential, since the plants were less than 3 years old at the time of harvest. Yields reported are for green beans with parchment removed. The 6-month harvest period necessary to obtain representative estimates of total yield was typical of coffee grown in Hawaii and corresponds to a period of asynchronous anthesis from February through July.

Leaf $\mathrm{C}$ isotope discrimination was negatively correlated with yield of green coffee beans among the 14 seedling populations studied (Fig. 1). Although correlations were significant for leaf samples obtained during June 1988 and Mar. 1990, the correlation coefficient was larger and the slope of the relationship steeper for leaves sampled in 1990. The $2 \%$ variation in $\Delta$ observed in Mar. 1990 corresponded to a 3-fold variation in yield (Fig. 1A). The range of $\Delta$ was nearly the same for leaves obtained on both sampling dates, but the relative ranking of the seedling populations with regard to $\Delta$ was not identical (Table 1). The $\Delta$ values obtained during Mar. 1990 should be considered more representative of the physiological and environmental conditions that prevailed during fruit development than those obtained during June 1988 because the leaves collected after harvest were present during the period of fruit maturation. The two seedling

Table 1. Yield and $\mathrm{C}$ isotope discrimination $(\Delta)$ in leaf tissue for 14 coffee cultivars planted during

\begin{tabular}{lccc}
\hline \hline $\begin{array}{l}\text { Secdling } \\
\text { population }\end{array}$ & $\begin{array}{c}\text { Yield } \\
(\mathrm{kg} / \mathrm{plot})\end{array}$ & Mar. 1990 & $\Delta(\% c)$ \\
\hline Yellow Caturta & $3.38 \pm 0.19$ & 18.48 & Junc 1988 \\
Pink Bourbon & $2.83 \pm 0.21$ & 19.42 & 19.38 \\
Catuai & $2.80 \pm 0.35$ & 18.38 & 18.71 \\
Guatcmalan & $2.74 \pm 0.27$ & 18.69 & 18.53 \\
Red Bourbon & $2.72 \pm 0.36$ & 19.42 & 19.97 \\
Mundo Novo & $2.60 \pm 0.23$ & 18.79 & 18.17 \\
Guadalupe & $2.57 \pm 0.41$ & 19.11 & 18.66 \\
Progeny 502 & $2.56 \pm 0.24$ & 19.74 & 19.96 \\
Yellow Bourbon & $2.52 \pm 0.28$ & 18.38 & 18.38 \\
Pache Grecn Tip & $2.16 \pm 0.26$ & 19.84 & 20.00 \\
Medio Cuerpo & $2.07 \pm 0.38$ & 19.21 & 18.70 \\
Blue Mountain & $2.06 \pm 0.21$ & 20.37 & 20.06 \\
Mokka & $1.06 \pm 0.25$ & 20.47 & 20.29 \\
San Ramon & $0.93 \pm 0.39$ & &
\end{tabular}




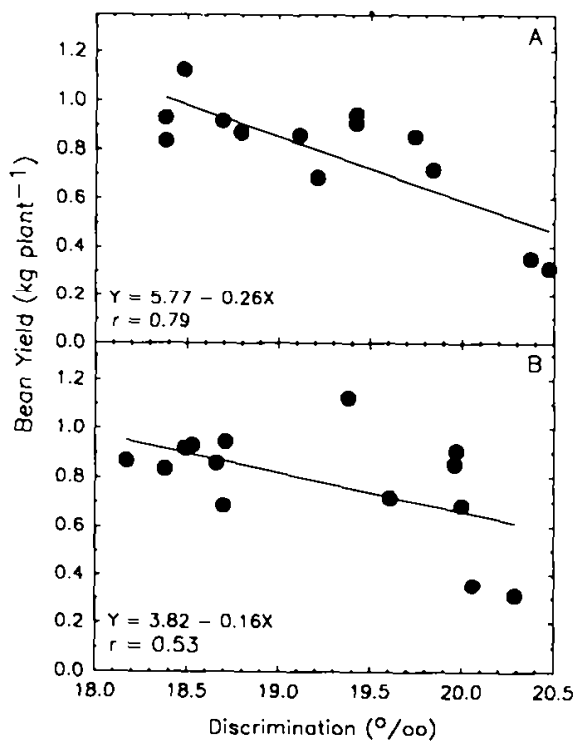

Fig. 1. Relationship between yield of green coffee beans in 14 coffee seedling populations and $\mathrm{C}$ isotope discrimination in leaves sampled during (A) Mar. 1990 and (B) June 1988. Yield per plant was obtained by dividing the yield per plot by the number of plants per plot. The correlation coefficients were significant at the 0.001 level in (A) and the 0.05 level in (B).

populations having the lowest yields (Table 1) exhibited somewhat atypical growth habits. 'San Ramon' is a dwarf cultivar characterized by extremely shortened internodes and a dense, hemispherical crown. Leaves of 'Mokka' are about half as wide as those of the other cultivars.

Since WUE increases with decreasing $\Delta$ and decreasing $\mathrm{p}_{\mathrm{i}}: \mathrm{p}_{\mathrm{a}}$, the results obtained here (Fig. 1) signify that yield in coffee was positively correlated with WUE. Similar results were obtained for peanut (Hubick et al., 1986) and sorghum (Hubick et al., 1990) genotypes, but a negative correlation between yield and WUE has been reported for wheat (Condon et al., 1987) and two range grass species (Johnson et al., 1990). The relationship between yield and $\Delta$ will depend on the mechanism by which a given level of $\mathrm{p}_{\mathrm{i}}: \mathrm{p}_{\mathrm{a}}$ is maintained. If genotypic variations in $p_{i}: p_{a}$ result from variations in photosynthetic capacity at similar levels of stomatal conductance, then yield and $\Delta$ should be negatively correlated. Conversely, when $\mathrm{p}_{\mathrm{i}}$ : $\mathrm{p}_{\mathrm{a}}$ varies as a result of changes in stomatal conductance with photosynthetic capacity remaining relatively constant, yield and $\Delta$ should be positively correlated. In a previous study of coffee, it was suggested that, when water supply is nonlimiting, yield should be negatively correlated with WUE, because higher WUE was associated with greater stomatal restriction of photosynthesis (Meinzer et al., 1990). The unexpected positive correlation between yield and WUE obtained with the 14 seedling populations studied here suggests that reduced photosynthetic rates in seedling populations with higher WUE may have been offset by the effects of a limited water supply on the seedling populations with lower WUE during the course of the study.
The results of the present study indicate that substantial variation in $\Delta$ exists among coffee cultivars and that leaf $\Delta$ analyses show promise as a means of selecting superior genotypes of long-lived woody crops.

\section{Literature Cited}

Condon, A.G., R.A. Richards, and G.D. Farquhar. 1987. Carbon isotope discrimination is positively correlated with grain yield and dry matter production in field-grown wheat. Crop Sci. 27:996-1001.

Farquhar, G.D., J.R. Ehleringer, and K.T. Hubick. 1989. Carbon isotope discrimination and photosynthesis. Annu. Rev. Plant Physiol. Plant Mol. Biol. 40:503-537.

Farquhar, G.D., M.H. O'Leary, and J.A. Berry. 1982. On the relationship between carbon isotope discrimination and the intercellular carbon dioxide concentration in leaves. Austral. J. Plant Physiol. 9:121-137.

Farquhar, G.D. and R.A. Richards. 1984. Isotopic composition of plant carbon correlates with water-use efficiency of wheat genotypes. Austral. J. Plant Physiol. 11:539-552.

Hubick, K.T., G.D. Farquhar, and R. Shorter 1986. Correlation between water use. efficiency and carbon isotope discrimination in diverse peanut (Arachis) germplasm. Austral. J. Plant Physiol. 13:803-816.

Hubick, K.T., G.L. Hammer, G.D. Farquhar, L.J. Wade, S. von Caemmerer, and S.A. Henderson. 1990. Carbon isotope discrimination varies genetically in $\mathrm{C}_{4}$ species. Plant Physiol. 91:534537.

Johnson, D.A., K.H. Asay, L.L. Tieszen, J.R. Ehleringer, and P.G. Jefferson. 1990. Carbon isotope discrimination: Potential in screening cool-season grasses for water-limited environments. Crop Sci. 30:338-343.

Martin, B. and Y.R. Thorstenson. 1988. Stable carbon isotope composition $\left({ }^{13} \mathrm{C}\right)$, water use efficiency, and biomass productivity of Lycopersicon esculentum, Lycopersicon pennellii, and the $F_{1}$ hybrid. Plant Physiol. 88:213-217.

Meinzer, F.C., G. Goldstein, and D.A. Grants. 1990. Carbon isotope discrimination in coffee genotypes grown under limited water supply. Plant Physiol. 92:130-135.

Wright, G.C., K.T. Hubick. and G.D. Farquhar. 1988. Discrimination in carbon isotopes of leaves correlates with water use efficiency of fieldgrown peanut cultivars. Austral. J. Plant Physiol. 15:815-825. 